\title{
From Meconomy to Weconomy and Back Again: Why the Sharing Economy Ultimately Just Merged with the Mainstream Economy
}

\author{
Victoria Bellotti \\ Lyft \\ San Francisco, USA
}

\begin{abstract}
Human economic behavior arises from primal instincts for survival and, despite our higher aspirations, it seems we just can't escape this fact. History shows that ideologically inspired experiments in egalitarian economic systems have always stalled or utterly failed. Nevertheless, after the financial market crash of 2008, many tech entrepreneurs were bewitched with the captivating and viral idea that technology could eradicate the barriers between individuals who wanted to share the resources they had. This led to the sudden much-hyped explosion of so-called "sharing economy" marketplace start-ups around 2010. However, research that I led showed that idealistic entrepreneurs misunderstood or forgot the basics of human economic behavior and my team's findings predicted the demise of all but the companies that were able to compete on classical economic terms (better value for money). I joined one such company, Lyft, because I shared the founders' vision for more sustainable transportation. Nevertheless, Lyft and the other rideshare and disruptive transportation companies must all compete fiercely to survive. It's a challenging road ahead, with many obstacles to overcome, but the destination is one I remain deeply committed to; I am still an idealist at heart!
\end{abstract}

Permission to make digital or hard copies of all or part of this work for personal or classroom use is granted without fee provided that copies are not made or distributed for profit or commercial advantage and that copies bear this notice and the full citation on the first page. Copyrights for components of this work owned by others than the author(s) must be honored. Abstracting with credit is permitted. To copy otherwise, or republish, to post on servers or to redistribute to lists, requires prior specific permission and/or a fee. Copyright 2018 SBC.

IHC 2018, Anais Estendidos do XVII Simpósio Brasileiro sobre Fatores Humanos em Sistemas Computacionais Outubro 22-26, 2018, Belém, Brasil

Palestra Convidada

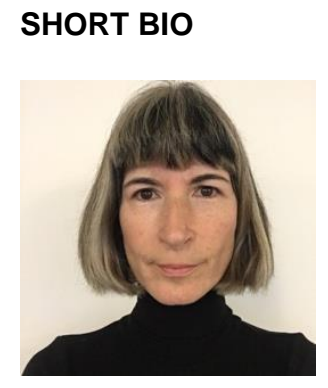

Victoria Bellotti is a User Experience Research Manager at Lyft, a member of the ACM SIGCHI Academy, an adjunct professor in the Jack Baskin School of Engineering at UCSC and an occasional advisor to start-ups. She studies people in their natural habitats to understand their practices, problems, and requirements for future technology, and designs and analyzes human-centered systems, focusing on user experience. Her recent research at PARC prior to joining Lyft focused on the sharing economy, user-centered design of context- and activity-aware computing systems, behavior change and persuasive computing. Her previous work at London University, UK, The British Government's Department of Trade and Industry, EuroPARC, Apple and PARC encompasses domains such as task and activity management, transportation, process control, computer-mediated communication, collaboration, and ubiquitous computing.

Dr. Bellotti received her Ph.D. in Human Computer Interaction from Queen Mary and Westfield College, an M.S. in Ergonomics, and a B.S. in Psychology from University College, all within London University in the United Kingdom. She is co-author of 20 patents and is an author or co-author on over 50 papers and book chapters. She also serves as an Associate Editor of the International Journal of HCI. She served as a co-chair of the "Understanding People" technical papers subcommittee for 2013 and 2014 of the ACM SIGCHI conference. In 2013 she was awarded membership of the ACM SIGCHI Academy for her contributions to the field and professional community of Human Computer Interaction. In 2016, she received a Lasting Impact award from the CSCW Community for coauthoring a paper with Dr. Paul Dourish on awareness and coordination in shared workspaces. 